\title{
- Comparison of selective media for isolation of Campylobacter jejuni/coli
}

\author{
FJ BOLTON, D COATES, PM HINCHLIFFE, L ROBERTSON
}

From the Public Health Laboratory, Preston Infirmary, Meadow Street, Preston, Lancashire

SUMMARY A comparison of Skirrow's, Butzler's, Blaser's, Campy-BAP and Preston media for Campylobacter spp was made using human, animal and environmental specimens. Butzler's medium gave the lowest isolation rate and Preston medium, which was the most selective, the highest isolation rate. Enrichment culture using Preston enrichment broth gave a higher isolation rate than direct plating onto Preston medium.

The isolation of campylobacters requires special selective techniques because of their microaerophilic nature and the many contaminating organisms found in specimens containing them. The first successful technique was differential filtration of faecal suspensions ${ }^{12}$ but this proved too time-consuming for the examination of large numbers of specimens. Subsequently isolation by direct culture of faeces was achieved on a selective medium ${ }^{3}$ incubated at 42$43^{\circ} \mathrm{C}$ in a microaerobic atmosphere.

Several selective media have been described. Skirrow's medium, ${ }^{3}$ Butzler's medium ${ }^{4}$ and Blaser's medium $^{5}$ are those most widely used for the isolation of campylobacters from human faeces in the United Kingdom, Europe and the USA respectively. A modification of Blaser's medium, called Campy-BAP (BBL) in the United States, is available as readypoured plates. Preston medium has recently been described by Bolton and Robertson. ${ }^{6}$

Some limited comparisons of selective agar media have been reported. Wells $\mathrm{et}^{\mathrm{al}} \mathrm{l}^{7}$ examined human faeces and found that Campy-BAP gave more isolates than either Skirrow's or Butzler's media. Patton et $\mathbf{l}^{\mathbf{8}}$ found the latter two media comparable for the isolation of campylobacters from dogs and cats. Bolton and Robertson ${ }^{6}$ reported that Preston medium was more selective and gave greater isolation than Skirrow's medium. Butzler's medium has been reported to be more selective than Skirrow's medium. ${ }^{9}$

The present paper compares the ability of Skirrow's, Butzler's, Blaser's, Campy-BAP, and Preston medium to isolate campylobacters from human faeces, cattle rectal swabs, lamb and pig caecal swabs, chicken cloacal swabs, and abattoir drain

Accepted for publication 11 August 1982 effluents. A simplified enrichment culture technique using a modified Preston enrichment broth ${ }^{6}$ is also described. As a preliminary investigation the ability

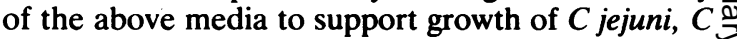
coli and nalidixic acid resistant thermophilic Campylobacter (NARTC) ${ }^{10}$ strains was determined:

\section{Material and methods}

\section{SELECTIVE MEDIA}

The compositions of the selective media used are given in Table 1. The composition of Butzler's $\mathbb{Q}$ medium is a modification of the original $^{12} \overrightarrow{\vec{P}}$ recommended by Oxoid Ltd which contains Blood $\frac{}{3}$ agar base No 2 (Oxoid CM271) and 5\% horse blood in place of thioglycollate agar and $15 \%$ sheep blood. Skirrow's, Butzler's and Blaser's media were prepared using Oxoid Ltd freeze-dried antibiotic supplements? SR69, SR85, and SR98 respectively. Campy-BAP medium was supplied as ready poured plates, and Preston medium was made up in the laboratory. The $O$ plates were dried at room temperature rather than in

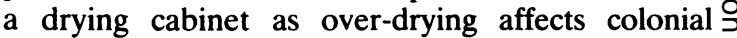
morphology. Enrichment culture was performed $I$ using Preston enrichment broth containing the aerotolerant supplement of George et al." ${ }^{11}$ The $N$ enrichment broth was distributed in $5 \mathrm{ml}$ volumes in $1 / 4 \mathrm{Oz}(7 \mathrm{~g})$ screw-capped bottles.

QUANTITATIVE TESTS USING PURE CULTURES OF ORGANISMS

The test organisms used were:

C jejuni biotype 1, (10) NCTC 11168

$C$ jejuni biotype II, (10) NCTC 11392

C coli NCTC 11353

C coli Preston 1098. pig isolate (6)

NARTC NCTC 11352

NARTC Preston 655, seagull isolate (6) 
Table 1 Compositions of selective media for campylobacter

\begin{tabular}{|c|c|c|c|c|c|}
\hline \multirow[t]{2}{*}{ Constituent } & \multicolumn{5}{|l|}{ Medium } \\
\hline & Skirrow's & Butzler's & Blaser's & Campy-BAP & Preston \\
\hline Nutrient agar & $\begin{array}{l}\text { Blood agar } \\
\text { base no 2 } \\
\text { (Oxoid CM271) }\end{array}$ & $\begin{array}{l}\text { Blood agar } \\
\text { base no 2 } \\
\text { (Oxoid CM271) }\end{array}$ & $\begin{array}{l}\text { Blood agar } \\
\text { base no } 2 \\
\text { (Oxoid CM271) }\end{array}$ & $\begin{array}{l}\text { Brucella } \\
\text { agar base } \\
(\mathrm{BBL})\end{array}$ & $\begin{array}{l}\text { Nutrient } \\
\text { broth no } 2 \\
\text { (Oxoid CM67) } \\
\text { in } 1.2 \% \text { New Zealand } \\
\text { agar }\end{array}$ \\
\hline Blood & $\begin{array}{l}5 \% \text { lysed } \\
\text { horse blood }\end{array}$ & $\begin{array}{l}5 \% \text { whole } \\
\text { horse blood }\end{array}$ & $\begin{array}{l}5 \% \text { lysed } \\
\text { horse blood }\end{array}$ & $\begin{array}{l}10 \% \text { whole } \\
\text { sheep blood }\end{array}$ & $\begin{array}{l}5 \% \text { lysed } \\
\text { horse blood }\end{array}$ \\
\hline $\begin{array}{l}\text { Antibacterials } \\
\text { Bacitracin IU/I }\end{array}$ & & 25000 & & & \\
\hline Cephalothin mg/l & & & 15 & 15 & \\
\hline $\begin{array}{l}\text { Cephazolin mg/l } \\
\text { Colistin IU/l }\end{array}$ & & $\begin{array}{r}15 \\
10000\end{array}$ & & & \\
\hline Novobiocin $\mathrm{mg} / \mathrm{l}$ & & 5 & & & \\
\hline $\begin{array}{l}\text { Polymixin IU/I } \\
\text { Rifampicin mg/l }\end{array}$ & $25(0)$ & & 2500 & 2500 & $\begin{array}{r}5000 \\
10\end{array}$ \\
\hline Trimethoprim mg/l & 5 & & 5 & 5 & 10 \\
\hline $\begin{array}{l}\text { Vancomycin } \mathrm{mg} / \mathrm{l} \\
\text { Antifungals }\end{array}$ & 10 & & 10 & 10 & \\
\hline $\begin{array}{l}\text { Amphotericin mg/l } \\
\text { Cyclohexamide mg/l }\end{array}$ & ${ }^{*} 100$ & 50 & 2 & 2 & 100 \\
\hline
\end{tabular}

$l(x) \mathrm{mg} / \mathrm{l}$ cyclohexamide was added to Skirrow's medium when used for non-human specimens.

The organisms were grown on Columbia horse blood agar plates incubated at $42^{\circ} \mathrm{C}$ for $24 \mathrm{~h}$ in an atmosphere approximately $10 \% \mathrm{O}_{2}, 10 \% \mathrm{CO}_{2}$ and $80 \% \mathrm{~N}_{2}$, which we have shown to be satisfactory for this group of organisms (to be published). Bacteria were harvested into $10 \mathrm{ml}$ of $0.1 \%$ peptone water, and standardised to a density of approximately $2 \times$ $10^{*}$ colony forming units (CFU)/ml using a Perkin Elmer 6/20 spectrophotometer at a wavelength of 450 $\mathrm{nm}$. Tenfold dilutions in $0.1 \%$ peptone water were prepared to give suspensions ranging from $10^{8}-10^{3}$ $\mathrm{CFU} / \mathrm{ml}$. The five selective media and a non-selective control medium (5\% lysed blood agar) were inoculated with six drops from a 50-dropper pipette by the method of Miles and Misra ${ }^{12}$ and the plates incubated for $48 \mathrm{~h}$ as described above. Experiments were done in triplicate and the mean count (of 18 drops) for each selective medium was compared with that of the control.

\section{TESTS WITH HUMAN, ANIMAL AND}

\section{ENVIRONMENTAL SPECIMENS}

The specimens cultured comprised 160 human faeces, 98 cattle rectal swabs, 99 lämb caecal swabs, -100 pig caecal swabs, 96 chicken cloacal swabs, and 100 abattoir drain effluent samples. Fifty of the human specimens were suspensions of known Campylobacter-positive faeces which had been stored at $-70^{\circ} \mathrm{C}$ in $20 \%$ glycerol broth. The remaining 110 specimens were suspensions of faeces, in $0.1 \%$ peptone water, from patients with diarrhoea. Cottontipped swabs from the animal specimens were broken off into $3 \mathrm{ml}$ of $0.1 \%$ peptone water in a bijou bottle and vortex mixed. Abattoir drain effluents, collected over a three-month period, were stored at $-70^{\circ} \mathrm{C}$, by adding $5 \mathrm{ml}$ of fluid to a bijou bottle containing $1 \mathrm{ml}$ of glycerol. These specimens and the faecal suspensions were inoculated onto selective media with cottontipped swabs which were then broken off into bottles of enrichment broth. The enrichment broths were incubated aerobically at $42^{\circ} \mathrm{C}$ for $24 \mathrm{~h}$, and then subcultured onto Preston medium. Direct plates were incubated (vide supra) and examined after 24,48 and $72 \mathrm{~h}$. Plates subcultured from enrichment broths were examined after 24 and $48 \mathrm{~h}$ incubation.

\section{Results}

Table 2 gives the mean counts of six test Campylobacter strains on the five selective media and on non-selective control medium. The differences were analysed by a two sample $t$ test for each strain separately at the $5 \%$ level of significance. All of the selective media gave significantly reduced counts of most, or all, of the test organisms relative to the counts on the control medium. Counts were not significantly reduced in the following cases: $C$ jejuni NCTC 11168 on Skirrow's medium, $C$ jejuni NCTC 11168 and $C$ coli NCTC 11353 on Blaser's medium, $C$ coli strains NCTC 11353 and Preston 1098 on CampyBAP medium, and $C$ jejuni NCTC 11168 and NARTC Preston 655 on Preston medium. If the sum of the counts obtained on control medium represents $100 \%$ recovery, then the recovery rates on individual selective media were $83 \%$ on Preston, $76 \%$ on Blaser's, $75 \%$ on Campy-BAP, $72 \%$ on Skirrow's, and $22 \%$ on Butzler's.

The results in Table 3 show that none of the 
Table 2 Mean counts of six Campylobacter strains tested on five selective media

\begin{tabular}{|c|c|c|c|c|c|c|}
\hline \multirow[t]{2}{*}{ Selective medium } & \multicolumn{6}{|c|}{ Campylobacter counts $\times 10^{*} \mathrm{CFU} / \mathrm{ml}$} \\
\hline & $\begin{array}{l}\text { C jejuni } \\
\text { NCTC } 11168\end{array}$ & $\begin{array}{l}\text { C jejuni } \\
\text { NCTC } 11392\end{array}$ & $\begin{array}{l}\text { C coli } \\
\text { NCTC } 11353\end{array}$ & $\begin{array}{l}C \text { coli } \\
\text { Preston } 1098\end{array}$ & $\begin{array}{l}\text { NARTC } \\
\text { NCTC } 11352\end{array}$ & $\begin{array}{l}\text { NARTC } \\
\text { Preston } 655\end{array}$ \\
\hline $\begin{array}{l}\text { Skirrow's } \\
\text { Butzler`s } \\
\text { Blaser`s } \\
\text { Campy-BAP } \\
\text { Preston } \\
\text { Control (non-selective) }\end{array}$ & $\begin{array}{l}7 \cdot 1(0 \cdot 5)^{*} \\
3 \cdot 6(1 \cdot 2) \\
8 \cdot 0(0 \cdot 8) \\
5 \cdot 8(0 \cdot 6) \\
8 \cdot 5(0 \cdot 8) \\
8 \cdot 8(1 \cdot 2)\end{array}$ & $\begin{array}{l}6 \cdot 2(0 \cdot 7) \\
1 \cdot 8(0 \cdot 5) \\
5 \cdot 7(0 \cdot 1) \\
7 \cdot 3(0 \cdot 9) \\
7 \cdot 2(0 \cdot 9) \\
8 \cdot 8(0 \cdot 5)\end{array}$ & $\begin{array}{l}0 \cdot 93(0 \cdot 04) \\
\mathrm{NC}+ \\
1 \cdot 5(0 \cdot 2) \\
1 \cdot 6(0 \cdot 1) \\
1 \cdot 2(0 \cdot 09) \\
1 \cdot 8(0 \cdot 1)\end{array}$ & $\begin{array}{l}1 \cdot 4(0 \cdot 06) \\
\mathrm{NC} \\
1 \cdot 2(0 \cdot 1) \\
1 \cdot 6(0) \\
1 \cdot 1(0 \cdot 03) \\
1 \cdot 8(0 \cdot 2)\end{array}$ & $\begin{array}{l}0.89(0.05) \\
\mathrm{NC} \\
1.0(0.06) \\
1.3(0.06) \\
1.1(0.06) \\
1.9(0.06)\end{array}$ & $\begin{array}{l}0.78(0.02) \\
\text { NC } \\
0.77(0.04) \\
0.52(0.05) \\
0.92(0.01) \\
0.92(0.06)\end{array}$ \\
\hline
\end{tabular}

* Figures in parentheses are the standard errors.

$+\mathrm{NC}$ : no count from the dilutions tested-that is $<5 \times 10^{5} \mathrm{CFU} / \mathrm{ml}$.

Table 3 Isolation of Campylobacter spp on direct plating and from enrichment broth

\begin{tabular}{|c|c|c|c|c|c|c|c|c|c|c|c|}
\hline \multirow{3}{*}{$\begin{array}{l}\text { Type of specimen } \\
\text { and numbers }\end{array}$} & \multicolumn{11}{|c|}{ Numbers of Campylobacter spp isolated on each medium } \\
\hline & \multicolumn{2}{|c|}{ Skirrow's } & \multicolumn{2}{|c|}{ Butzler's } & \multicolumn{2}{|c|}{ Blaser's } & \multicolumn{2}{|c|}{ Campy-BAP } & \multicolumn{2}{|c|}{ Preston } & \multirow{2}{*}{$\begin{array}{l}\text { Enrichment } \\
\text { broth }\end{array}$} \\
\hline & $24 h$ & $48 h$ & $24 h$ & $48 h$ & $24 h$ & $48 h$ & $24 h$ & $48 h$ & $24 h$ & $48 h$ & \\
\hline $\begin{array}{l}\text { Human faeces }(50) \\
\text { Human faeces }(110) \\
\text { Cattle }(98) \\
\text { Lamb (99) } \\
\text { Pig }(100) \\
\text { Chicken (96) } \\
\text { Drain effluents (100) } \\
\text { Totals (653) }\end{array}$ & $\begin{array}{r}4 \\
6 \\
14 \\
0 \\
66 \\
91 \\
2 \\
183\end{array}$ & $\begin{array}{r}13 \\
8 \\
18 \\
1 \\
87^{*} \\
91 \dagger \\
3 \\
221\end{array}$ & $\begin{array}{r}1 \\
6 \\
6 \\
0 \\
17 \\
80 \\
5 \\
115\end{array}$ & $\begin{array}{r}10 \\
9 \\
14 \\
1 \\
67 \\
90 \\
12 \\
203\end{array}$ & $\begin{array}{r}4 \\
7 \\
12 \\
0 \\
83 \\
92 \\
2 \\
200\end{array}$ & $\begin{array}{r}12 \\
8 \\
20 \\
1 \\
91 \\
93 \\
2 \\
227\end{array}$ & $\begin{array}{r}1 \\
6 \\
8 \\
0 \\
37 \\
81 \\
0 \\
133\end{array}$ & $\begin{array}{r}5 \\
8 \\
16 \\
0 \\
83 \\
92 \\
0 \\
204\end{array}$ & $\begin{array}{r}7 \\
8 \\
16 \\
0 \\
86 \\
92 \\
10 \\
219\end{array}$ & $\begin{array}{r}15 \\
9 \\
19 \\
0 \\
94 \\
94 \\
19 \\
250\end{array}$ & $\begin{array}{l}\text { Not done } \\
13 \\
40 \\
16 \\
99 \\
95 \\
34 \\
297\end{array}$ \\
\hline
\end{tabular}

* One campylobacter overgrown at $48 \mathrm{~h}$.

† Two campylobacters overgrown at $48 \mathrm{~h}$.

selective media gave maximum recovery after $24 \mathrm{~h}$ incubation. The percentage of Campylobacter isolates on each medium after $24 \mathrm{~h}$ incubation compared with the number after $48 \mathrm{~h}$ incubation was Skirrow's 83\%, Butzler's 57\%, Blaser's $88 \%$, Campy-BAP $65 \%$ and Preston medium $88 \%$. No further isolations were recorded after $48 \mathrm{~h}$ incubation. The three positive lamb caceal swabs grew one colony only on each of Skirrow's, Butzler's and Blaser's media, indicating that campylobacters in these specimens were probably present in very low numbers. Enrichment culture proved essential for maximum isolation from the majority of specimens but especially from cattle rectal swabs, lamb caceal swabs and drain effluents. It failed to isolate campylobacters from four drain effluents which were positive on direct plating. Of 603 specimens cultured by both enrichment broth and direct plating, campylobacters were isolated from 297 by enrichment compared with 247 on direct plating, a $20 \%$ increase in isolation rate. The isolation rates of the selective media, expressed as a percentage of the total isolation by enrichment are: Skirrow's $74 \%$, Butzler's 68\%, Blaser's 76\%, Campy-BAP 69\% and Preston medium $84 \%$.

Tables $4 \mathrm{a}$ to $4 \mathrm{e}$ show the maximum recovery possible by using any two media and the results indicate that the Preston medium should always be $\frac{\AA}{\unrhd}$ included in any combination.

Table 5 shows the qualitative growth of campylobacters from specimens on each of the selective media. The percentage of isolates givingo heavy or moderate growth was: Skirrow's $52 \%$, Butzler's 46\%, Blaser's 57\%, Campy-BAP 50\% and? Preston medium 53\%.

Table 6 shows the contamination rate associated with each of the media. The Preston medium was the most selective followed by Butzler's, Skirrow's, Blaser's and Campy-BAP. The contaminants varied음 with the type of specimen. Coliforms, Pseudomonas $D$ spp and streptococci were the most frequent contaminants on all media and yeasts occasionally $\mathcal{O}^{-}$ grew on Skirrow's, Butzler's and Preston medium. Fungi were common contaminants from drain effluent and cattle specimens on all of the media but $\omega$ their growth was most reduced on Preston medium.? Although contaminants grew on many of the plateso from human and animal specimens they did not $\mathbb{\Phi}$ greatly interfere with Campylobacter isolation.? However, in the case of drain effluents the greater selectivity of Preston medium facilitated isolation of $\underset{\mathbb{D}}{\stackrel{O}{\circ}}$ campylobacters from these specimens, whereas growth of campylobacters on the other selective $\stackrel{\AA}{\varrho}$ media could not be detected in the presence of 
Table 4 Total number of Campylobacter positive isolates recoverable with any combination of two media

\begin{tabular}{|c|c|c|c|c|}
\hline \multicolumn{5}{|c|}{ (4a) Catle (23 positive by direct culture) } \\
\hline $\begin{array}{l}\mathrm{Bu}(14) \\
\mathrm{BI}(20) \\
\mathrm{CB}(16) \\
\mathrm{Pr}(19)\end{array}$ & $\begin{array}{l}20 \\
22 \\
20 \\
23\end{array}$ & $\begin{array}{l}22 \\
19 \\
20\end{array}$ & $\begin{array}{l}20 \\
21\end{array}$ & 21 \\
\hline & $\underset{\dot{x}}{\stackrel{x}{x}}$ & $\ddot{\oplus}$ & $\bar{\oplus}$ & $\ddot{~}$ \\
\hline (4b) $C h$ & posit & lirect & & \\
\hline $\begin{array}{ll}\mathrm{Bu} & (90) \\
\mathrm{Bl} & (93) \\
\mathrm{CB} & (92) \\
\mathrm{Pr} & (94)\end{array}$ & $\begin{array}{l}93 \\
93 \\
93 \\
94\end{array}$ & $\begin{array}{l}93 \\
92 \\
94\end{array}$ & $\begin{array}{l}93 \\
94\end{array}$ & 94 \\
\hline
\end{tabular}

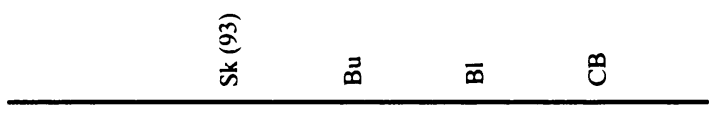

(4c) Drain effluents (23 positive by direct culture)

\begin{tabular}{lrrrr}
\hline Bu (12) & 14 & & & \\
Bl (2) & 4 & 13 & 2 & \\
CB (0) & 3 & 12 & 20 & 19 \\
Pr (19) & 20 & 21 & 20 \\
\hline
\end{tabular}

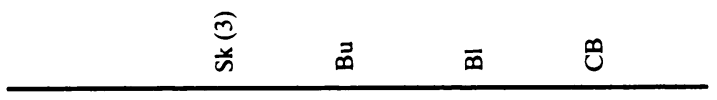

\begin{tabular}{lllll}
\hline (4d) & Pig (95 positive by direct culture) \\
\hline Bu (67) & 89 & & & \\
$\mathrm{BI}(91)$ & 93 & 89 & & \\
$\mathrm{CB}(83)$ & 91 & 88 & 93 & \\
$\mathrm{Pr}(94)$ & 94 & 94 & 95 & 94 \\
\hline
\end{tabular}

\begin{tabular}{|c|c|c|c|}
\hline 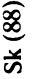 & Фี & $\overline{\boldsymbol{m}}$ & $\stackrel{\infty}{0}$ \\
\hline
\end{tabular}

(4e) 50 Human faeces (19 positive by direct culture)

\begin{tabular}{lllll}
\hline Bu (10) & 14 & & & \\
BI (12) & 16 & 13 & 12 & \\
CB (5) & 13 & 10 & 12 & 15 \\
Pr (15) & 17 & 16 & 16 & \\
\hline
\end{tabular}

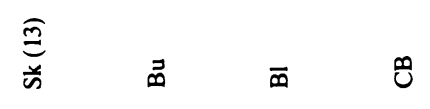

Sk $=$ Skirrow's.

$\mathrm{Bu}=$ Butzler's.

$\mathrm{Bl}=$ Blaser's.

CB $=$ Campy-BAP

$\mathrm{Pr}=$ Preston.

Figures in parentheses indicate the number of isolates on each medium.
Table 5 Qualitative growth of campylobacters isolated from all specimens on direct culture after $48 \mathrm{~h}$ incubation

\begin{tabular}{|c|c|c|c|c|c|}
\hline \multirow{2}{*}{$\begin{array}{l}\text { Qualitative } \\
\text { growth }\end{array}$} & \multicolumn{5}{|c|}{ Numbers of campylobacters isolated on each medium } \\
\hline & Skirrow's & Butzler's & Blaser's & Campy-BAF & P Preston \\
\hline $\begin{array}{l}+++ \\
++ \\
+ \\
\pm \\
\text { Total }\end{array}$ & $\begin{array}{l}77(35)^{*} \\
38(17) \\
48(22) \\
58(26) \\
221^{\dagger}\end{array}$ & $\begin{array}{c}61(30) \\
32(16) \\
22(11) \\
88(43) \\
203\end{array}$ & $\begin{array}{r}77(34) \\
52(23) \\
44(19) \\
54(24) \\
227\end{array}$ & $\begin{array}{l}59(29) \\
44(21) \\
40(20) \\
61(30) \\
204\end{array}$ & $\begin{array}{l}72(29) \\
61(24) \\
44(18) \\
73(29) \\
250\end{array}$ \\
\hline
\end{tabular}

$+++=$ growth over all of the inoculated area.

$++=$ growth over two thirds of the inoculated area.

$+=>10$ colonies on the primary inoculum area.

$\pm=<10$ colonies on the primary inoculum area.

* Figures in parentheses are the percentages.

$\dagger$ Three isolates were overgrown at $48 \mathrm{~h}$.

Table 6 Qualitative growth of contaminants from all specimens after $48 \mathrm{~h}$ incubation on direct culture plates

\begin{tabular}{lccccc}
\hline \multirow{2}{*}{$\begin{array}{l}\text { Qualitative } \\
\text { growth }\end{array}$} & Numbers of contaminants grown on each medium \\
\cline { 2 - 6 } & Skirrow's & Butzler's & Blaser's & Campy-BAP & Preston \\
\hline+++ & 38 & 10 & 28 & 29 & 7 \\
++ & 88 & 30 & 75 & 106 & 15 \\
+ & 63 & 53 & 107 & 118 & 37 \\
+ & 104 & 137 & 141 & 158 & 99 \\
Total & 293 & 230 & 351 & 411 & 158 \\
\hline
\end{tabular}

contaminants. On Skirrow's medium campylobacters which were evident after $24 \mathrm{~h}$ incubation were occasionally overgrown at $48 \mathrm{~h}$ by Proteus spp and swarming Bacillus spp. An index of the performance of each of the selective media has been calculated as the ratio of the total number of campylobacters isolated (Table 5) to the total number of plates with contaminants (Table 6). The performance index of each medium was: Skirrow's 0.75, Butzler's 0.88, Blaser's 0.65, Campy-BAP 0.5 and Preston medium 1.58. The higher the index the better the performance.

\section{Discussion}

Culture plates were incubated under the same conditions of time, temperature and atmosphere and therefore the differences in selectivity between the various media can be attributed to the influence of their three major components-that is, basal medium, growth promoting additives and inhibitory supplements. Skirrow's and Blaser's media differ only in their antibiotic content, whilst Blaser's and campy-BAP have identical antibiotic supplements but different basal medium and blood content. The differences in results obtained with these two pairs of media demonstrate that all of the components contribute to the overall properties.

Blood agar base No 2 is recommended by Oxoid as a basal medium for Skirrow's, Butzler's and Blaser's 
media, and its incorporation in all of these reduced variation and allowed the selectivity of each antibiotic mixture to be evaluated. Skirrow's medium was formulated for the isolation of campylobacters from human faeces and does not contain an antifungal agent but we added cyclohexamide when the medium was used for non-human specimens so that its performance could be more fairly assessed.

The specimens were chosen for several reasons: faeces from humans because of the clinical importance of the disease in man; swabs from cattle and chickens because of their epidemiological links with human infection; swabs from pigs because they are a readily available source of $C$ coli; swabs from lambs in order to increase the sampling of animals whose meat is sold for human consumption; and finally drain effluents as examples of heavily contaminated environmental specimens. We were unable to include specimens which normally contain the NARTC strains. However, the results of the quantitative counts from pure cultures (Table 2) give some indication of the ability of the various media to support the growth of these strains. Furthermore, Bolton and Robertson ${ }^{6}$ have shown that Preston medium gives greater isolation of these strains than Skirrow's medium when examining specimens from seagulls.

When campylobacters in specimens are numerous they can easily be detected in culture after $24 \mathrm{~h}$ incubation. Preston medium and Blaser's medium gave the greatest number of isolates at this time, and Butzler's medium the least. Wells et al ${ }^{7}$ and Patton $e t$ $a l^{8}$ reported increased isolation after $72 \mathrm{~h}$ incubation but we found no improvement after $48 \mathrm{~h}$, due mainly to overgrowth by contaminants. We conclude, therefore, that $48 \mathrm{~h}$ is the optimum time for examination of primary plates.

Butzler's medium proved too inhibitory to support the growth of pure cultures of $C$ coli and NARTC strains in quantitative tests, and was the least effective medium for isolating $C$ coli from pig swabs. It did, however, support the growth of $C$ jejuni biotypes I and II strains which are more likely to be encountered in human disease. Our results demonstrate that the composition of Butzler's medium used in this study is unsatisfactory. In other studies (unpublished) we incorporated Butzler's antibiotic mixture into Columbia agar (Oxoid) with 5\% horse blood, and found that Campylobacter isolations from animal and avian specimens were comparable to those obtained on Preston medium.

Skirrow's medium lacked selectivity and heavy growths of Proteus sp and Bacillus sp interfered with the isolation of campylobacters especially from cattle, chicken and drain effluent specimens, an observation previously made by Bolton and Robertson. ${ }^{6}$ The addition of cyclohexamide improved the selectivity of $\frac{\stackrel{0}{*}}{2}$ the medium compared with the results of that earlier $\frac{\text { - }}{-}$ survey and without this antifungal agent many of the $\overrightarrow{\overrightarrow{\mid}}$ plates inoculated with cattle specimens and drain effluents would have been overgrown with saprophytic fungi.

On the basis of antibiotic content alone, one would $\frac{\bar{\rho}}{\widetilde{\sigma}}$ have expected Blaser's medium and Campy-BAP to $\cong$ have behaved similarly but this was not the case; $\%$ Blaser's medium gave a better isolation rate and was $\vec{\circ}$ slightly more selective. Campy-BAP gave better results in the quantitative counts from pure cultures $\vec{\omega}$ than it did in the specimen cultures owing to contaminants in the latter growing on the medium.? We observed that Campylobacter colonial $\omega$ morphology was atypical on Campy-BAP, especially that of $C$ coli. These strains produced colonies which $\infty$ tended to be more grey, discrete and homogeneous $ᄋ$ and which were, in many cases, difficult to distinguish from coliform colonies. On the other four media the $c$ colonial appearance of the campylobacters was the characteristic moist, spreading, translucent growth. We consider that this difference in colonial morphology on Campy-BAP makes identification $\vec{\bullet}$ more difficult and time-consuming.

Preston medium was found to be the most selective and to give the best isolation rate from the majority of specimens. Its recovery of campylobacters from dilutions of pure cultures was better than the others and it had the highest performance index. Its $\underset{\perp}{\mathscr{Q}}$ selectivity and superior isolation rate is best $\overrightarrow{\vec{F}}$ demonstrated from the results of the drain effluents $\frac{0}{3}$ where all other media behaved poorly.

On primary plating none of the media examined was able to isolate all the strains of Campylobacter encountered and two selective agars at least would be? needed to improve the isolation rate. The best $\frac{5}{3}$ combination of media for direct plating would include the Preston medium and one other, selected on the $\stackrel{0}{\circ}$ basis of the data contained in Tables $4 a-4 e$. However, $₹$

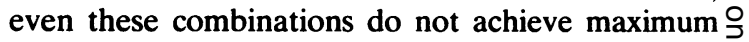
recovery.

The modified enrichment broth which does not require a microaerobic atmosphere gave greater $\bar{N}$ isolation than all the selective agars; recovery of ${ }^{\circ}$ campylobacters from cattle, lamb and drain effluents $N$ was increased by $74 \%$, "433\%" and $48 \%$ respectively. Gilchrist $e t a^{13}$ reported that their enrichment $\sigma$ technique failed to increase Campylobacter isolationo from human faeces. The Preston enrichment broth $\Phi$ has been used for this purpose in two separate trials ? and gave an approximately $15 \%$ increase in isolation 0 rate (unpublished data). Many of these cases were $\stackrel{\vec{\Phi}}{\vec{D}}$ asymptomatic or patients excreting the organism for $\stackrel{\Phi}{\square}$ prolonged periods. Although enrichment is not $\stackrel{\mathbb{Q}}{\AA}$ necessary for the diagnosis of acute clinical infections 
it is of value in epidemiological studies.

Campylobacter strains which grew only in enrichment broth, or which failed to grow on some of the selective agars, were selected for biotyping by the method of Skirrow and Benjamin ${ }^{10}$ in order to determine if particular biotypes failed to grow on specific media. Only $C$ coli strains and Butzler's medium showed evidence of such an association.

This study indicates that at present the most satisfactory commercially available selective media are Blaser's and Skirrow's made to the Oxoid Ltd formulations. However, Preston medium gave the best overall performance for the isolation of campylobacters from all types of specimens. We suggest that the best combination of media for maximum isolates from all types of specimen is Preston enrichment broth with Preston medium.

We wish to thank the BBL division of Becton Dickinson and Company for their co-operation and contribution of Campy-BAP ready poured plates used in this study.

\section{References}

' Dekeyser P, Gossuin-Detrain M, Butzler JP, Sternon J. Acute enteritis due to related vibrio: first positive stool cultures. $J$ Infect Dis 1972;125:390-2.
${ }^{2}$ Butzler JP, Dekeyser P, Detrain M, Dehaen F. Related vibrio in stools. J Pediatr 1973;82:493-5.

${ }^{3}$ Skirrow MB. Campylobacter enteritis: a "new" disease. Br Med J 1977;ii:9-11.

${ }^{4}$ Lauwers S, DeBoeck M, Butzler JP. Campylobacter enteritis in Brussels. Lancet 1978; i:604-5.

${ }^{5}$ Blaser M, Cravens J, Powers BW, Wang WL. Campylobacter enteritis associated with canine infection. Lancet 1978;ii:979-81.

- Bolton FJ, Robertson L. A selective medium for isolating Campylobacter jejuni/coli. J Clin Pathol 1982;35:462-7.

${ }^{7}$ Wells JG, Bopp CA, Blaser MJ. Evaluation of selective media for the isolation of Campylobacter jejuni. In: Newell DG, ed. Campylobacter: epidemiology, pathogenesis and biochemistry. Lancaster: MTP Press, 1982:80-2.

${ }^{8}$ Patton CM, Mitchell SW, Potter ME, Kaufmann AF. Comparison of selective media for primary isolation of Campylobacter fetus subsp jejuni. J Clin Microbiol 1981;13:326-30.

${ }^{9}$ Butzler JP, Skirrow MB. Campylobacter enteritis. Clin Gastroenterol 1979;8:737-65.

${ }^{10}$ Skirrow MB, Benjamin J. Differentiation of enteropathogenic Campylobacter. J Clin Pathol 1980;33:1122.

" George HA, Hoffman PS, Smibert RM, Krieg NR. Improved media for growth and aerotolerance of Campylobacter fetus. J Clin Microbiol 1978;8:36-41.

${ }_{12}$ Miles AA, Misra SS, Irwin JO. The estimation of the bactericidal power of the blood. J Hyg 1938;38:732-49.

${ }^{13}$ Gilchrist MJR, Grewell CM, Washington JA. Evaluation of media for isolation of Campylobacter fetus subsp jejuni from faecal specimens. J Clin Microbiol 1981;14:393-5.

Requests for reprints to: Dr D Coates, Public Health Laboratory, Royal Infirmary, Meadow Street, Preston PR1 6PS, England. 